This is a post-peer-review, pre-copyedit version of an article published in Journal of Polymers and the Environment. The final authenticated version is available online at: http://dx.doi.org/10.1007/s10924-017-0982-9 


\title{
Environmental impact assessment of Polylactide(PLA)/Chicken feathers biocomposite materials.
}

\author{
Gemma Molins ${ }^{1}$, María Dolores Álvarez ${ }^{1}$, Núria Garrido², Jorge Macanás ${ }^{1}$, Fernando Carrillo ${ }^{1,3}$ \\ ${ }^{1}$ Departament d'Enginyeria Química (EQ), Universitat Politècnica de Barcelona (UPC), Terrassa, Spain \\ ${ }^{2}$ Departartament de Màquines i Motors Tèrmics (MMT), Universitat Politècnica de Barcelona (UPC), \\ Terrassa, Spain
${ }^{3}$ Institut d'Investigació Tèxtil i Cooperació Industrial de Terrassa (INTEXTER), Universitat Politècnica de Barcelona (UPC), Terrassa, Spain

Corresponding author: Gemma Molins, Colom, 108222 Terrassa, Barcelona, Spain gemma.molins@upc.edu-Tel. +34 937398250 - Fax. +34 937398225

\begin{abstract}
Suggested running head: Impact assessment of Polylactide(PLA)/Chicken feathers biocomposite materials.
\end{abstract}

\begin{abstract}
The aim of this study is to analyse the environmental impacts (EIs) of the process of preparation of new biocomposite materials obtained from polylactide (PLA) and chicken feathers (CFs). Two CFs stabilization methods and different percentages of CFs have been studied. The EIs of these new composites were compared to the impact of virgin PLA. Cradle-to-gate life cycle inventories were assessed for $0 \%$ to $35 \%$ v/v of CFs in a CFs/PLA biocomposite. Two CFs stabilization processes, autoclave and surfactant, were tested and compared with the aim to prioritize one of them from the environmental point of view. A composite plate of $184 \times 184 \times 2.2 \mathrm{~mm}^{3}$ was defined as the functional unit. Autoclave stabilization process exhibited lower environmental impact compared with surfactant stabilization process mainly due to both the lower requirements of electricity and water and the reduced pollution loads of the generated wastewater. Thus, the autoclave process was selected as the standard method when comparing the EIs of the proposed CFs/PLA biocomposites. In this sense, the addition of CFs to PLA matrix proportionally reduces all the EIs compared to pure PLA due to the replacement of PLA with CFs. This behaviour can be explained because the PLA production accounts for the $99 \%$ of the impact of the biocomposite. Consequently, CFs conveniently stabilized might be an alternative raw material to prepare CFs/PLA biocomposites with less environmental impact compared to pure PLA.
\end{abstract}

Keywords: Chicken feathers. Biocomposites. Green composites, Waste recovering, Life cycle assessment (LCA). Polylactide (PLA). 


\section{Introduction}

Plastic composite materials are made of a polymer matrix and a reinforcement (e.g. particles, fibres, fabric), which originally were synthetic (such as fiberglass, aramid or carbon fibres). Nevertheless, since 1990's a ground-breaking has been made in the research and development of composite materials by the proposal of using many natural fibres, mainly of vegetable origin such as hemp or flax as reinforcement to obtain biocomposites [1-4]. In spite of the advantages of biocomposites, it is important to ponder the technical drawbacks of these natural fibres and their environmental impacts (EIs) [5]. Some authors have stated that bio-based materials may, in some cases, have more EIs than their conventional plastics (fossil fuel-derived polymers) [6]. In this sense, it is worth mentioning that plant fibres imply a land use that can compete with food production.

In contrast, alternative biogenic materials such as keratine-based chicken feathers (CFs) derived from waste of poultry industry can be a potential alternative [7-11] as they are a waste material, produced in large quantities, with properties similar to wool [12], that do not compete with human food production and have been scarcely used up to now [13]. CFs are an abundant, ubiquitously, economic and biogenic keratin waste[14]. Global production and world consumption of chicken meat has grown by $17 \%$ in the last 5 years [15]. Accordingly, the waste generated in the production process has increased at the same extend. CFs are a part of such waste, representing $6 \%$ of the live weight of the animal $[16,17]$. Worldwide production of CFs reached about 6.000.000 tons in 2012. The European annual contribution (EU-27) is about 700.000 tones, being Spain the fifth contributor in the EU-27 [15].

This paper presents the results obtained from the life cycle assessment (LCA) of a bio-based biocomposite made of polylactide (PLA), as the polymer matrix, and CFs. The replacement of PLA matrix with CFs is expected to offer environmental advantages since the production of biodegradable or bio-based plastic composites in a sustainable manner could reduce the noticeable EIs of using conventional plastic and composites, which not only consume non-renewable energy finite resources (fossil fuel derived polymers), but also impact heavily upon waste disposal[18]. It is worth considering that the composite material was engineered to have the highest proportion of CFs having similar mechanical properties (Young's Modulus, yield strength and density [19]) to acrylonitrile butadiene styrene (ABS), polypropylene (PP) or Polyamide [20]. 
Therefore, CFs could be valorised to manufacture environmentally friendly composites for application in

several industries such as construction, automotive, packaging, textile, etc. due to its particular physical and mechanical properties, such as light weight and specific modulus and tensile strength [8, 21-25].

PLA has been selected as the polymeric matrix due to its mechanical properties, being one of the preferred polymers among bioplastics [26-28].

Hence, this study aims to provide a comprehensive cradle-to-gate life cycle inventory (LCI) on CFs/PLA biocomposites to investigate their environmental load. Several CFs stabilization methods and different percentages of CFs have been studied. The environmental impact of these new composites was compared to the impact of virgin PLA. To the best of our knowledge, such a study is reported here for the first time despite the fact that the number of publications regarding either composites or biocomposites containing CFs has grown considerable in the last decade, being most of them included in a recent review [29].

\section{Materials and methods}

\subsection{Goal, functional unit and scope}

The goal of this study is to assess the EIs of new developed composite materials obtained with CFs and PLA. Several amounts of CFs (from $0 \%$ to $35 \% \mathrm{v} / \mathrm{v}$ of $\mathrm{CFs}$ ) have been analyzed. The EIs of this new material were compared to the EIs of using neat PLA in order to assess the potential environmental benefits of introducing CFs in the plastic material. Additionally, two CFs stabilization processes were tested, compared and analyzed with the aim to prioritize the most environmentally friendly one.

Given the adequate mechanical properties of the new composite material tested in our laboratory $[19,30]$, a composite plate of $184 \times 184 \times 2.2 \mathrm{~mm}^{3}$ was defined as the functional unit in this study for calculation and comparative purposes.

In this study, a volume functional unit has been considered rather than a mass functional unit because the differences between the densities of composites cannot be overlooked [1]. Previous studies carried out by our research group revealed that CFs have lower density than PLA [31]. Therefore the specific volume of the composite is strongly depending on the percentage of CFs in it. Accordingly, industrial specifications for the production of a product will be related to a volume rather than a mass.

This study includes the three main steps required for the preparation of a CFs/PLA biocomposite: chicken feathers stabilization, crushing and composite plate manufacturing. First, CFs were pre-treated to transform them into a stable technical material (stabilization process). Two different stabilization 
processes were considered: i) treatment with a cationic benzalkonium chloride type surfactant and ii) treatment with steam in autoclave. The second step involved the crushing process to reduce the particle size of the CFs ( $1 \mathrm{~mm}$ or less) and the subsequent drying. At last, a selected percentage (10, 20 or $35 \%$ $\mathrm{v} / \mathrm{v}$ ) of the stabilized crushed chicken feathers (SCCF) was blended with PLA to obtain the functional unit. A detailed block diagram of the complete process of manufacturing a CFs/PLA composite plate is shown in Figure 1.

Current study considers the poultry raising out of the scope, as CFs are an inexpensive product in this process. A discussion about the effect of the inclusion of the EIs of the poultry raising activity is offered in sections 2.2.4 (allocation) and section 4 (discussion) of the manuscript.

The following EIs lie beyond the scope of the study: the construction of the building and the manufacture of machines. Moreover, transports are not considered since its environmental burdens may be considered negligible taking into account that the location of the plant is not defined at present and the CFs stabilization should be placed in a location nearby the slaughterhouse.

Data sources were thoroughly checked in order to elude those considered unreliable. Foreground data from CFs stabilization, crushing and manufacturing processes consist of a mean from several laboratory measures. Composition data from cationic surfactant used in stabilization process were provided by the manufacturer. Environmental data related to the components of the surfactant were assessed using ecoinvent 3.0 database [32]. Wastewaters generated by both the autoclave and surfactant stabilization processes were analysed applying Standard Methods [33]. In the case of PLA inventory, data were collected from most recent data published by NatureWorks for ecoinvent 3.0 database.

Besides, background data were obtained from ecoinvent 3.0 database [32].

\subsection{Life cycle inventory (LCI)}

Four CFs/PLA composite plates $\left(184 \times 184 \times 2.2 \mathrm{~mm}^{3}\right)$ were considered; the studied proportions of CFs were $0 \%, 10 \%, 20 \%$ and $35 \%$ v/v. Detailed data from this LCI study are summarized in Table I and Table II and results are discussed below.

\subsubsection{Stabilization processes}

CFs used in this study came from the slaughterhouse. There, they were incorporated to the scalding water bath and impregnated with other organic waste (such as fat, blood or sludge) [34]. For this reason, CFs are often subjected to rapid degradation processes and it is necessary to transform them into a technical 
material through a stabilization process. Two stabilization processes, with autoclave or with surfactant,

have been studied in order to compare them from the environmental point of view.

The surfactant stabilization process consisted in washing CFs with a cationic benzalconium surfactant solution at a concentration of $0,7 \% \mathrm{v} / \mathrm{v}$ during 1 hour with a bath ratio of 40:1 in a lab washing apparatus with controlled conditions (Linitest ${ }^{\circledR}$ ), followed by rinsing with $500 \mathrm{ml}$ of deionized water. Once washed, CFs were dried at $60^{\circ} \mathrm{C}$ for 24 hours in a hot air oven.

Energy consumptions associated with the washing process were determined considering the washing time and the laboratory washing equipment power measured with a wattmeter, while energy consumptions associated with the drying process were theoretically calculated taking into account both the specific heat capacity of the CFs, with a value of $1,31 \pm 0,10 \mathrm{~kJ} / \mathrm{kg} \mathrm{K}$ that was experimentally determined by Differential Scanning Calorimetry (DSC) analysis, and the water content, with an average of $41 \%$ [31]. The Chemical Oxygen Demand (COD), Biological Oxygen Demand (BOD 5 ), suspended solids, oils, total nitrogen (by Kjeldalh method) present in wastewater generated in this process were also analysed and considered for the assessment of the EIs.

Besides, autoclave consisted in sanitizing CFs with steam at $135^{\circ} \mathrm{C}$ for 20 minutes, followed by a CFs drying step as stated before. Energy consumptions associated with the sanitizing and drying steps were determined as in the case of surfactant stabilization. Likewise, wastewater generated was analyzed following the above mentioned tests.

\subsubsection{Crushing process}

The following step consisted in crushing stabilized CFs with a cutting mill machine (RETSCH SM 100, Germany) to a maximum size of $1 \mathrm{~mm}$. After that, CFs were dried in order to eliminate the remaining humidity. The energy consumption involved in the cutting mill was measured experimentally in the laboratory considering the crushing time and the cutting mill machine power measured with a wattmeter. The energy consumption of the drying step has been calculated theoretically as stated before. The inputs and outputs associated with both processes, stabilization and crushing, are shown in Table I.

\subsubsection{Plate manufacturing process}

CFs/PLA composites were prepared using a compounding laboratory machine following the process reported elsewhere [30]. Briefly, preparation of the composite material involved compounding the selected percentage of SCCFs $(10,20$ or $35 \% \mathrm{v} / \mathrm{v})$ with the PLA matrix in a heated mixer and, subsequently, conforming the mixture by hot-pressing to obtain the composite material (see Figure 1). 
Particularly, matrix and SCCFs filler were mixed using a Brabender mixer type W 50 EHT PL (Brabender ${ }^{\circledR} \mathrm{GmbH} \& \mathrm{Co} . \mathrm{KG}$, Germany) heated at $180^{\circ} \mathrm{C}$ for $5 \mathrm{~min}$ at $50 \mathrm{rpm}$. After mixing, the blend was consolidated at $100 \mathrm{kN}$ and $180^{\circ} \mathrm{C}$ for $5 \mathrm{~min}$ in a Collin Mod. P 200E (Dr. Collin GmbH, Germany) hot plates press machine forming square plates, measuring $184 \times 184 \times 2.2 \mathrm{~mm}^{3}$.

For the assessment of neat PLA, the most recent data related to the process production were used, i.e. the data published by ecoinvent 3.0 for SimaPro version 8.0 software [35]. Energy consumption data corresponding to the manufacture of the biocomposite plate were experimentally collected with a power grid analyser under steady state conditions. Data revealed that the energy consumption is independent of the percentage of SCCFs used, at least in the studied range (between 0 to $35 \% \mathrm{v} / \mathrm{v}$ ), hence energy consumption was equal for all the composite plates. Table II summarizes the inventory data regarding the material and energy consumption necessary for the preparation of composite plates including different percentage of SCCFs filler $(\% \mathrm{v} / \mathrm{v})$.

\subsubsection{Allocation}

The allocation rules between the meat production and the feathers deserve a special mention. Although the rising and breeding of chicken for chicken meat production is a process with high EIs [34], the impacts related to chicken production should not be allocated to feathers (which account for the 5-7\% weight of the animal's live weight [17]). Taking into account the ILCD handbook published by the European Commission, Join Research Center [36], it is crucial to determine the causal relationships between each non-functional flow and the co-products as a first criterion. CFs are inexpensive wastes of the chicken meat production [37], and there is not causal or economic relationship between the raising of poultry (non-fuctional flow) and the CFs (co-products). All the flows needed for fattening, as well as the chemicals used for the de-feathering are only imputable to the chicken meat.

Consequently, we have excluded those environmental impacts strictly attributed to chicken meat production.

\subsection{Life Cycle assessment (LCA)}

\subsubsection{Selection of impact categories (IC)}

Inputs and outputs of elementary flows were translated into impact indicator results [38] and only classification and characterization steps were considered. For classification, all the inventory data were assigned into ICs according to their contribution to different environmental problems. For 
characterization, elementary flows were modelled to quantify their contribution to each IC and results

were aggregated per IC. Since there is no scientific consensus regarding which ICs should be considered when assessing the EIs associated with biopolymers and composites [39], the following ICs from the CML-IA baseline calculation method [40] were selected: abiotic depletion, abiotic depletion (fossil fuels), global warming (GWP100a), ozone layer depletion (ODP), human toxicity, fresh water aquatic ecotoxicity, marine aquatic ecotoxicity, terrestrial ecotoxicity, photochemical oxidation, acidification and eutrophication. Furthermore, due to the biogenic origin of the PLA the inclusion of land use indicators has been considered. These land use indicators (agricultural and urban land occupation and natural land transformation) have been adapted from the ReCiPe method [41].

\section{Results}

\subsection{Stabilization process}

Previous studies conducted by our team revealed that the type of CFs stabilization process does not significantly affect the mechanical properties of the composites within the range of CFs compositions studied [24]. Thus, the inventory data related to the stabilization processes studied was taken into account in order to compare them from the environmental point of view with the aim to prioritize one of them.

The results of impact characterization (Table III) indicated that, for all the EIs categories, the autoclave stabilization method exhibited lower EIs compared with the surfactant method. This is mainly caused by ten-fold lower consumption of energy ( $1.1 \mathrm{~kJ} / \mathrm{g}$ of $\mathrm{CF}$ in autoclave vs $12.5 \mathrm{~kJ} / \mathrm{g}$ of CF in surfactant) and water (from $40 \mathrm{~g} / \mathrm{g}$ of $\mathrm{CF}$ in autoclave to $240 \mathrm{~g} / \mathrm{g}$ of $\mathrm{CF}$ in surfactant) of the autoclave process. In addition, the autoclave process yielded wastewater with a lower content of pollutants. The higher pollutant loads and water needs of the surfactant process are a consequence of the nature of the process itself, which is based in a washing water bath. In this case, the bath ratio was to be high enough to cover the CFs and as a result higher amount of water was needed compared to the autoclave method. Moreover, the mechanical action induced during the surfactant method removed more efficiently the organic matter localized onto the surface of the CFs contributing to the increase of the pollutants in the wastewater. Conversely, this mechanical action was absent in the autoclave process since the sterilization was produced by the action of steam on a static packed column of CFs.

To sum up, from the environmental point of view, it was demonstrated that the best stabilization method for cleaning CFs was the autoclave process. Accordingly, this method was selected as the standard to 
efficiently stabilize the CFs in the following experiments. Thus, on account of the fact that the following

steps for the production of the composite plate (crushing and plate manufacturing) were independent of the CFs stabilization process used, only inventory data related to the autoclave process were used to assess the EIs of compounding and conforming the targeted composite materials.

\subsection{Compounding and conforming the CFs/PLA composites}

The environmental impact for preparing CFs/PLA composites, using CFs stabilized by autoclave and the PLA matrix, was analysed taking into account the inventory data corresponding to the processes of autoclave stabilization, crushing (Table I) and manufacturing of the composite plate (Table II). Main results obtained are shown in Figure 2. These results revealed that the addition of CFs significantly reduced all the EIs considered for the loaded composite materials compared to pure PLA. Indeed, the increase on the CFs percentage in a CFs/PLA composite plate involved environmental benefits since the amount of PLA required to prepare the composite was reduced, reducing the environmental impacts related to the use of PLA. Looking in deeper detail it can be detected than the observed impact reduction caused by the addition of CFs was directly proportional to the amount of PLA replaced for all the ICs studied. This behaviour can be explained taking into account that the PLA production accounts for the 99\% of the EIs of the biocomposite in all the analized ICs considered (Figure 3 and Table IV), even when the highest amount of CFs is considered.

When analysing EIs of PLA in greater depth, it can be seen that the major impacts are due to the maize grain production and the energy consumption in the PLA plant production, see Figure 4.

\section{Discussion}

Despite the noticeable EIs related to PLA production that have been identified, PLA is one of the preferred bioplastics with a lower environmental impact compared to conventional plastics (fossil derived) $[5,10,26,27]$. In this sense, the use of PLA as a matrix to prepare biocomposites has some advantages from the environmental point of view. However, as it has been demonstrated in this study and in previous works [42], the main EIs of the PLA-based biocomposites come primarily from the PLA production. So the addition of CFs to PLA matrix might be presented as a solution to reduce the EIs associated with the biocomposite preparation. Particularly, from the results of this study, the presence of CFs reduces the EIs proportionally to the percentage of CFs added since the contribution of the CFs to the EIs is very low compared to the PLA (Figure 3). In this sense, the same trend was observed when using 
natural cellulosic fibers (i.e. flax fibers). However, it is important to remark that when flax is combined

with PLA, the EIs related to the flax are higher than the corresponding to CFs [42]. Thus, CFs can be thought as a more environmentally friendly alternative compared to flax fibers.

As regards to the resource utilization, some key aspects can be considered. On the one hand, the incorporation of biogenic CFs waste into composite materials (up to $35 \% \mathrm{v} / \mathrm{v}$ ) prevents their disposal or incineration and therefore a better use of the resources. On the other hand, the incorporation of increasing amounts of CFs into composites would reduce the depletion of alternative natural resources (such as flax or jute) as well as the consumption of polymeric matrices derived from biomass (i.e. PLA) or fossil (conventional thermoplastics) resources.

Recyclability is another factor worth considering. In this sense, although these biocomposites are difficult to recycle, the use of both a biodegradable matrix and a biodegradable filler would allow the valorisation of composite waste as compost [39].

The introduction of CFs in PLA composites proportionally decreases all ICs studied, such as land occupation or abiotic depletion, all related to the production of PLA. Besides, it is worthy to emphasise that the incorporation of low density CFs $\left(0.9 \mathrm{~g} / \mathrm{cm}^{3}\right)$ [31] in composites for a specific application may also indirectly contribute to lower the environmental footprint due to the potential savings that can be achieved if the targeted products are used for instance in transportation, what was not considered in this work.

Taking into account the aforementioned allocation rules [36], the impact of breeding chicken should not be considered in this study because CFs are judged as worthless waste derived from the chicken meat production process [37]. Even bearing in mind that fact, an estimation of the effect of this factor has been made in order to evaluate the theoretical impact of such allocation. To do so, values of EIs due to raising and slaughtering chickens that are available in the literature [34, 43] have been taken. In particular these references allow us to analyse some ICs (Abiotic depletion, acidification, eutrophication, global warming, terrestrial ecotoxicity and photochemical oxidation) related to up to five possible scenarios that differ from each other in both the functional unit and the percentage of meat produced per chicken. In all cases, the mass of CFs has been considered as a $6 \%$ of the whole animal weight [17]. With these premises, it has been verified that, for the ICs considered in this study, the variation provoked by these additional impacts does not exceed $3 \%$, except in the category of abiotic depletion where farming represents a $98 \%$ of the impact due to the feed production (see Table $\mathrm{V}$ for results of the analysis). 


\section{Conclusions}

It has been proved that CFs, conveniently stabilized, might be an alternative raw material to prepare CFs/PLA bio-based composites with less environmental impact compared with neat PLA materials since a proportional reduction of EIs was pointed out when increasing the percentage of CFs in the composite plate. Consequently, the industrial use of CFs for preparation of bio-based composites could potentially consume a high percentage of the annually generated CFs that are currently discarded and treated as a solid waste.

From the environmental point of view, if an industrial production of the CFs/PLA biocomposites were implemented, the autoclave process should be considered as stabilization treatment since this treatment has shown lower EIs due to the lower consumption of resources, such as water and energy, and the lower loads found in wastewater, compared to those involved in the washing with surfactant.

\section{Recommendations and perspectives}

It is worth to note that inventory data related with CFs stabilization and compounding steps considered in this LCA study were mainly recorded at laboratory scale because this new material is currently under investigation. In this sense, it would be interesting to extend the study to potential scenarios at industrial plant scale to better identify and quantify the environmental profile of the production process of a specific product made of CFs/PLA for an interested industrial sector (f.i., automotive or construction). As mentioned before, this work was not focused on any targeted industrial product. Consequently, this study did not include the EIs associated to these new composite materials at the end of its life. Nevertheless, it would be advisable to include those EIs in future works related to any targeted product so as to have a complete analysis of the life cycle of the material and also to draw more accurate conclusions.

The avoided burdens due to the valorization of CFs waste are another factor worth considering. There is a lack on bibliographic data related to the quantification of the EIs caused by the management of the feathers as a waste. In this direction it seems advisable to extend this work in the future to include feathers waste management scenarios (incineration, land filling, industrial processing to prepare hydrolysates for pet food production) to set up an accurate database supported by experimental studies. 


\section{Acknowledgments}

FEDER and the Spanish Ministry of Science and Innovation Funding (MAT 2010-17057) are gratefully acknowledged.

\section{References}

1. Joshi S, Drzal L, Mohanty A, Arora S (2004) Are natural fiber composites environmentally superior to glass fiber reinforced composites? Compos Part A Appl Sci Manuf 35:371-376.

2. Corbiere-Nicollier T, Gfeller-Laban B, Lundquist L, et al. (2001) Life cycle assessment of biofibres replacing glass fibres as reinforcement in plastics. Resour Conserv Recycl 33:267-287.

3. Wotzel K, Wirth R, Flake M (1999) Life cycle studies on hemp fibre reinforced components and ABS for automotive parts. Die Angew Makromol Chemie 272:121-127.

4. Xu X, Jayaraman K, Morin C, Pecqueux N (2008) Life cycle assessment of wood-fibrereinforced polypropylene composites. J Mater Process Technol 198:168-177.

5. Álvarez-Chávez CR, Edwards S, Moure-Eraso R, Geiser K (2012) Sustainability of bio-based plastics: general comparative analysis and recommendations for improvement. J Clean Prod 23:47-56. doi: 10.1016/j.jclepro.2011.10.003

6. Baillie C (2004) Green Composites, Polymer composites and the environment. Woodhead Publishing Ltd, Cambridge

7. Barone J, Schmidt W (2006) Composites and films comprised of avian feather keratin. 10/805,558:

8. Wool R, Hong C (2005) Development of a bio-based composite material from soybean oil and keratin fibers. J Appl Polym Sci 95:1524.

9. Barone J, Schmidt W (2005) Polyethylene reinforced with keratin fibers obtained from chicken feathers. Compos Sci Technol 65:173-181.

10. Cheung $\mathrm{H}$ yan, Ho M po, Lau K tak, et al. (2009) Natural fibre-reinforced composites for bioengineering and environmental engineering applications. Compos Part B Eng 40:655-663. 
11. Huda S, Yang Y (2009) Feather Fiber Reinforced Light-Weight Composites with Good Acoustic Properties. J Polym Environ 17:131-142.

12. Wallenberger F, Weston N (2004) Natural fibers, plastics and composites. Kluwer Academic Publishers, Boston

13. Garraín D, Vidal R, Franco V (2007) Land use in LCA of biomaterials. 3rd Int. Conf. Life Cycle Manag. LCM 2007

14. Reddy N (2007) Structure and properties of chicken feather barbs as natural protein fibers. J Polym Environ 15:81-87.

15. AVEC (2015) Annual report of the Assiciation of Poultry Processors and Poultry Trade in the EU countries. Brussels

16. Carrillo F, Macanás J, Colom X, et al. (2012) Use of chicken feathers waste for the fabrication of composite materials. In: 15th Eur. Conf. Compos. Mater. Venice, p 1-8.0026

17. Instituto Markin (2009) Estudio sobre los subproductos generados en los mataderos de pollos. Año 2009. Valencia

18. Garraín D, Vidal R, Martínez P, et al. (2007) How green are biopolymers? 16th Int. Conf. Eng. Des. ICED’07

19. Cañavate J, Aymerich J, Garrido N, et al. Properties and optimal manufacturing conditions of chicken feathers/PLA biocomposites. J. Compos. Mater.

20. Granta Design Limited (2012) CES EduPack software.

21. Kock J (2006) Physical and mechanical properties of chiquen feather materials. THES, Georgia Institute of Technology

22. Wrzesniewska-Tosik K, Wawro D, Ratajska M, Steplewski W (2007) Novel biocomposites with feather keratin. Fibres Text East Eur 15:157.

23. Cheng S, Lau K, Liu T, et al. (2009) Mechanical and thermal properties of chicken feather fiber/PLA green composites. Compos Part B Eng 40:650-654. doi: 
10.1016/j.compositesb.2009.04.011

24. Carrillo F, Rahhali a., Canavate J, Colom X (2013) Biocomposites using waste whole chicken feathers and thermoplastic matrices. J Reinf Plast Compos 32:1419-1429. doi: $10.1177 / 0731684413500546$

25. Colom X, Rahalli A, Cañavate J, Carrillo F (2013) Properties and optimal manufacturingconditions of chicken feathers thermoplastic biocomposites. J. Compos. Mater.

26. Vink ETH, Glassner DA, Kolstad JJ, et al. (2007) ORIGINAL RESEARCH: The eco-profiles for current and near-future NatureWorks ${ }^{\circledR}$ polylactide (PLA) production. Ind Biotechnol 3:58-81.

27. Madival S (2009) Assessment of the environmental profile of PLA, PET and PS clamshell containers using LCA methodology. J Clean Prod 17:1183-1194. doi: 10.1016/j.jclepro.2009.03.015

28. Shen L, Worrell E, Patel M (2010) Present and future development in plastics from biomass. Biofuels, Bioprod Biorefining 4:25-40.

29. Martínez-Hernández AL, Velasco-Santos C (2012) Keratin fibers from chicken feathers: structure and advances in polymer composites. In: Renke Dullaart et al (ed) Keratin Struct. Prop. Appl. Nova Science Publishers, Inc., pp 149-211

30. Garrido N, Aymerich J, Colom X, et al. (2011) Optimal manufacturing conditions of chicken feathers/PLA biocomposites. 12th Mediterr. Congr. Chem. Eng.

31. Macanás J, Molins G, Álvarez MD, et al. (2011) Physicochemical characterization of a valorisable waste: chicken feathers. In: 12th Mediterr. Congr. pp 21-25

32. Weidema BP, Bauer C, Hischier R, et al. (2013) Data quality guidelines for the ecoinvent database version 3: Overview and methdology (final).

33. Eugene W. Rice, Rodger B. Baird, Andrew D. Eaton LSC (2012) Standard Methods for the Examination of Water and Wastewater. Am Water Work Assoc Public Work Assoc Environ Fed 1469.

34. González-García S, Gomez-Fernández Z, Dias AC, et al. (2014) Life Cycle Assessment of broiler 
chicken production: a Portuguese case study. J Clean Prod 74:125-134. doi: 10.1016/j.jclepro.2014.03.067

35. PRé Consultants (2014) SimaPro 8.0 Life Cycle Assessment Software Package.

36. European Comission, Joint Research Centre, Institute for Environment and Sustainability (2010) International reference Life Cycle Data System (ILCD) Handbook - General quide for Life Cycle Assessment - Detailed quidance, First. doi: 10.2788/38479

37. Ministrerio de Agricultura P y A (2007) Libro blanco subproductos de origen animal no destinados al consumo humano. Ministrerio de Agricultura, Pesca y Alimentación, Madrid

38. Organisation IS (2006) ISO 14040:2006 Environmental managenet - Life cycle assessment Principles and framework. Norma ISO:

39. Vidal R (2009) Life cycle assessment of composite materials made of recycled thermoplastics combined with rice husks and cotton linters. Int J life cycle Assess 14:73-82.

40. Heijungs R, Huppes G, Guinee J (2010) Life cycle assessment and sustainability analysis of products, materials and technologies. Toward a scientific framework for sustainability life cycle analysis. Polym Degrad Stab 95:422-428.

41. Goedkoop M, Heijungs R, Huijbregts MAJ, et al. (2013) ReCiPe 2008 A life cycle impact assessment method which comprises harmonised category indicators at the midpoint and the endpoint level. Netherlands

42. Le Duigou A (2012) PLLA/flax mat/balsa bio-sandwich-environmental impact and simplified life cycle analysis. Appl Compos Mater 19:363-378.

43. Prudêncio da Silva V, van der Werf HMG, Soares SR, Corson MS (2014) Environmental impacts of French and Brazilian broiler chicken production scenarios: an LCA approach. J Environ Manage 133:222-31. doi: 10.1016/j.jenvman.2013.12.011 


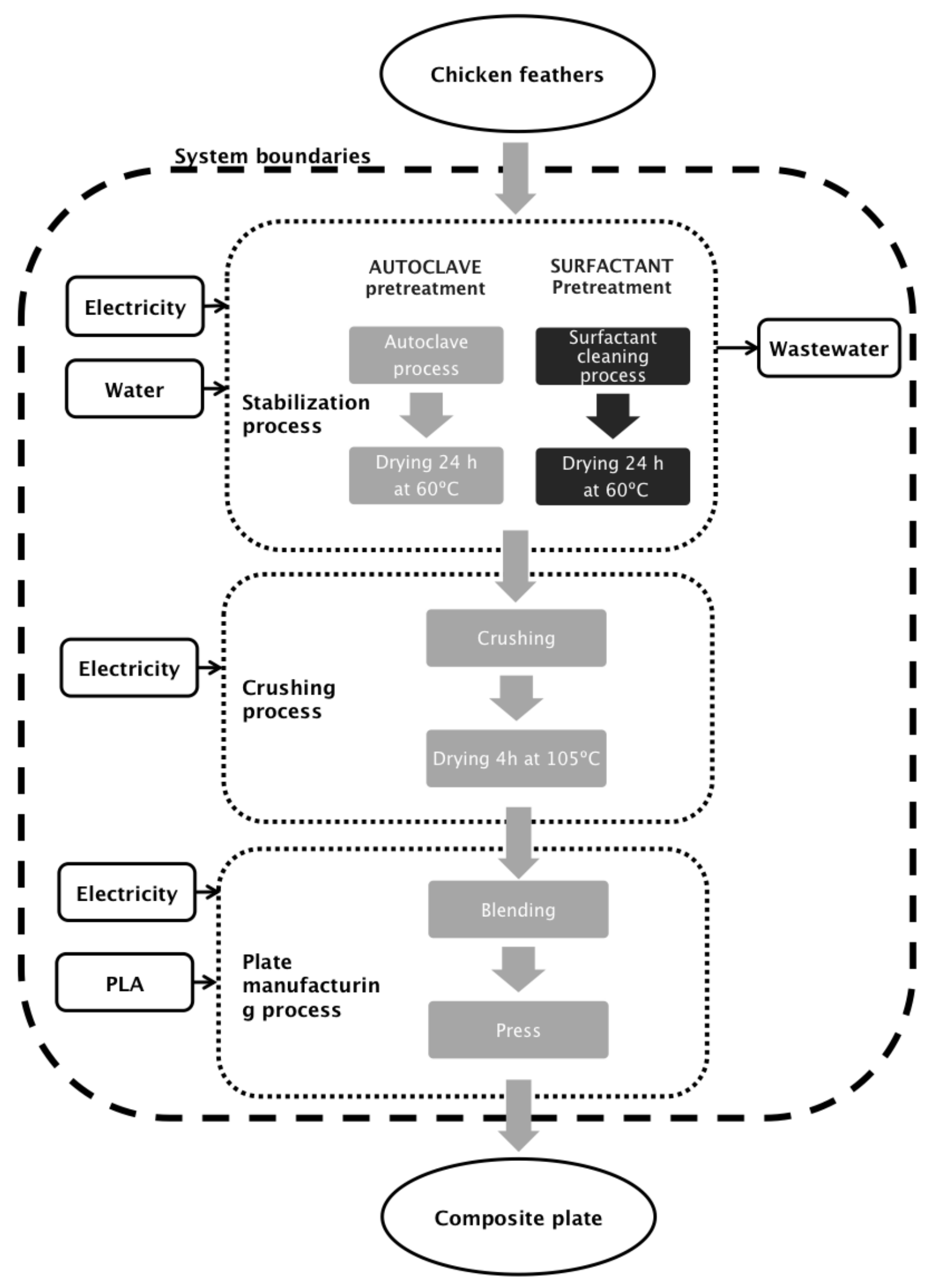

Figure 1: Scope of the manufacturing of a PLA/CFs composite plate. 


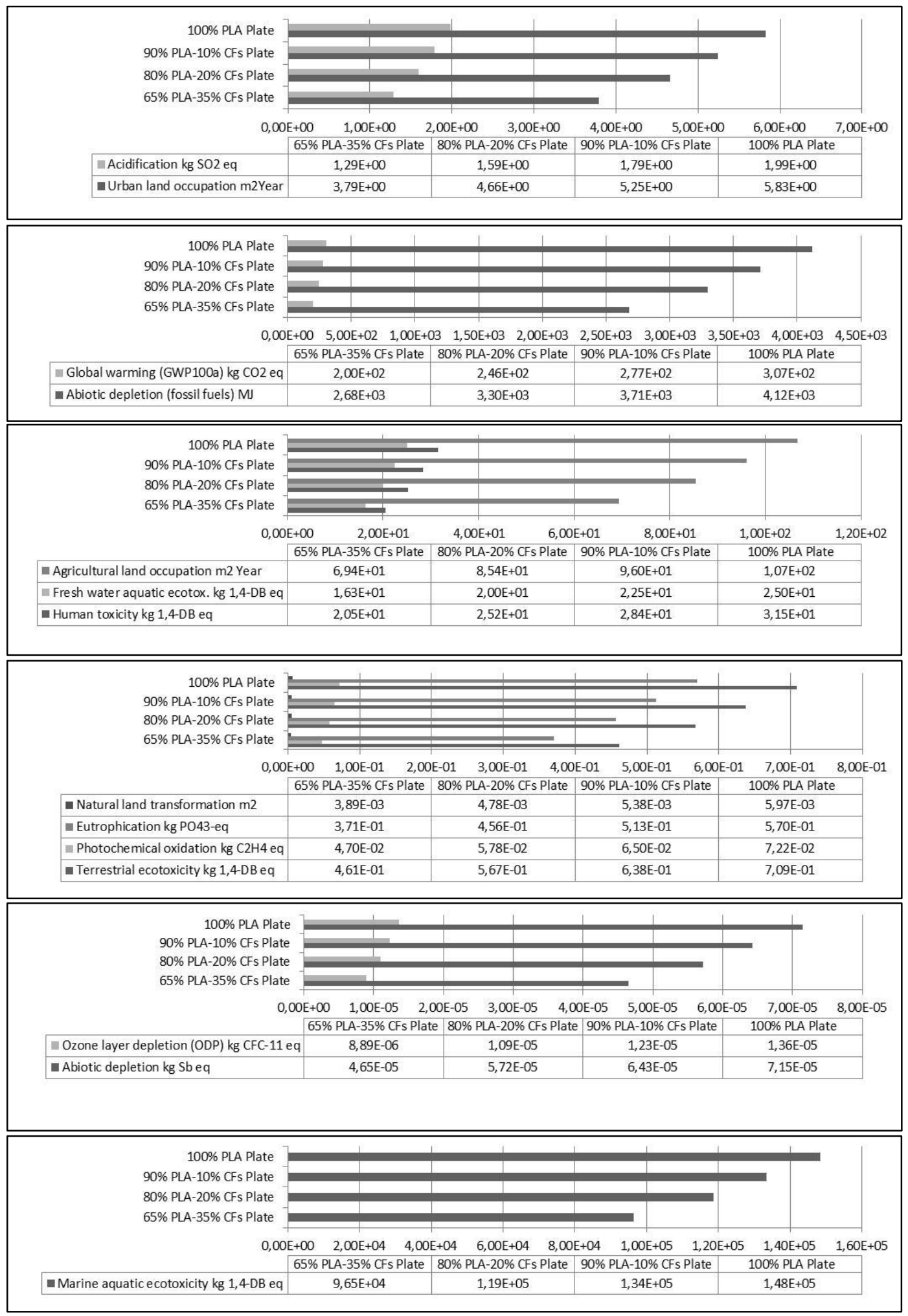

Figure 2: Characterization of composite plates with different \% of CFs with CML-IA EU25 modified method and excluding infrastructure processes and long-term emissions. 


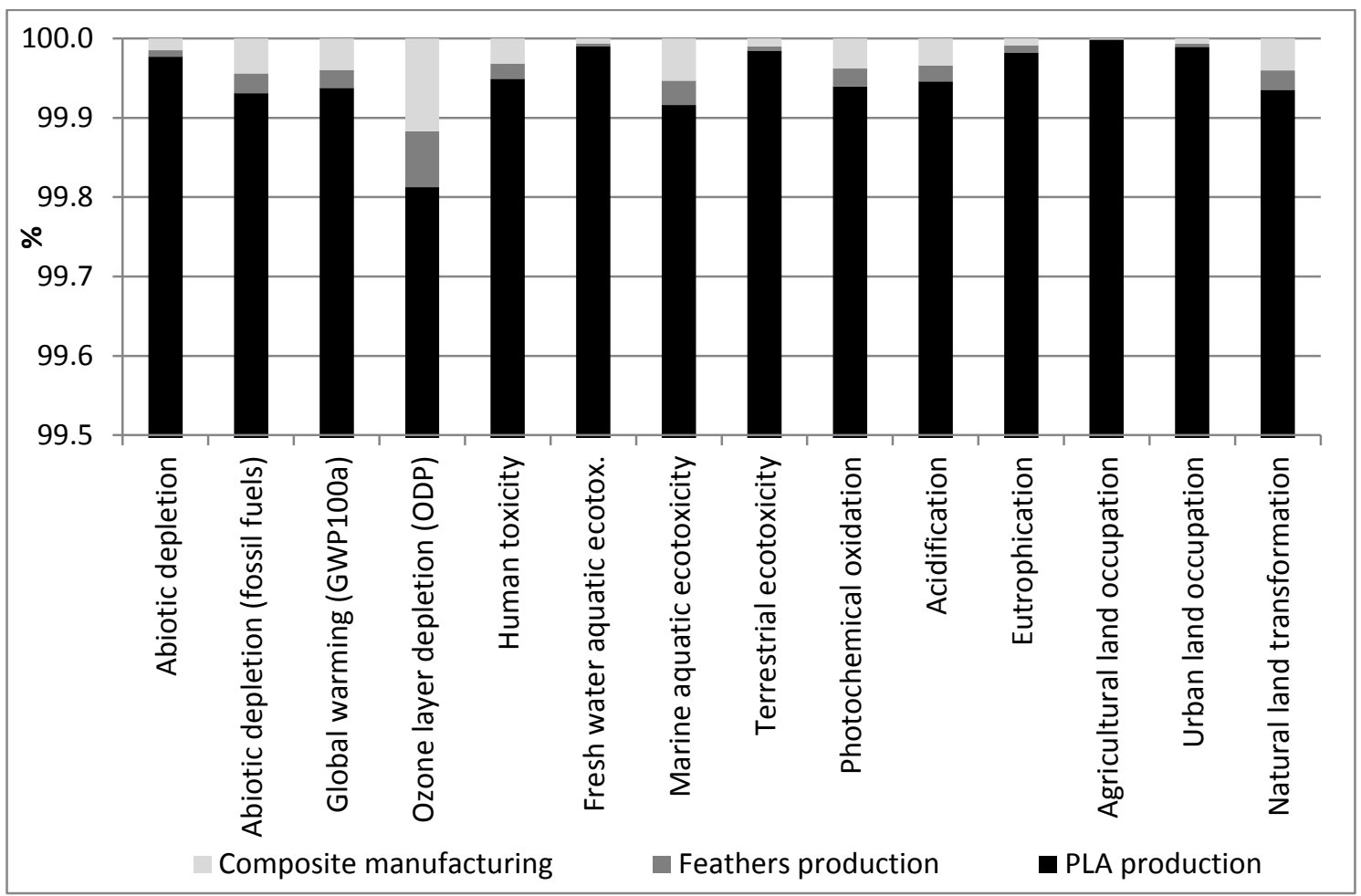

Figure 3 CML Characterization factors of composite plate with $20 \%$ of CFs with CML-IA EU25 modified method and excluding infrastructure processes and long-term emissions. 


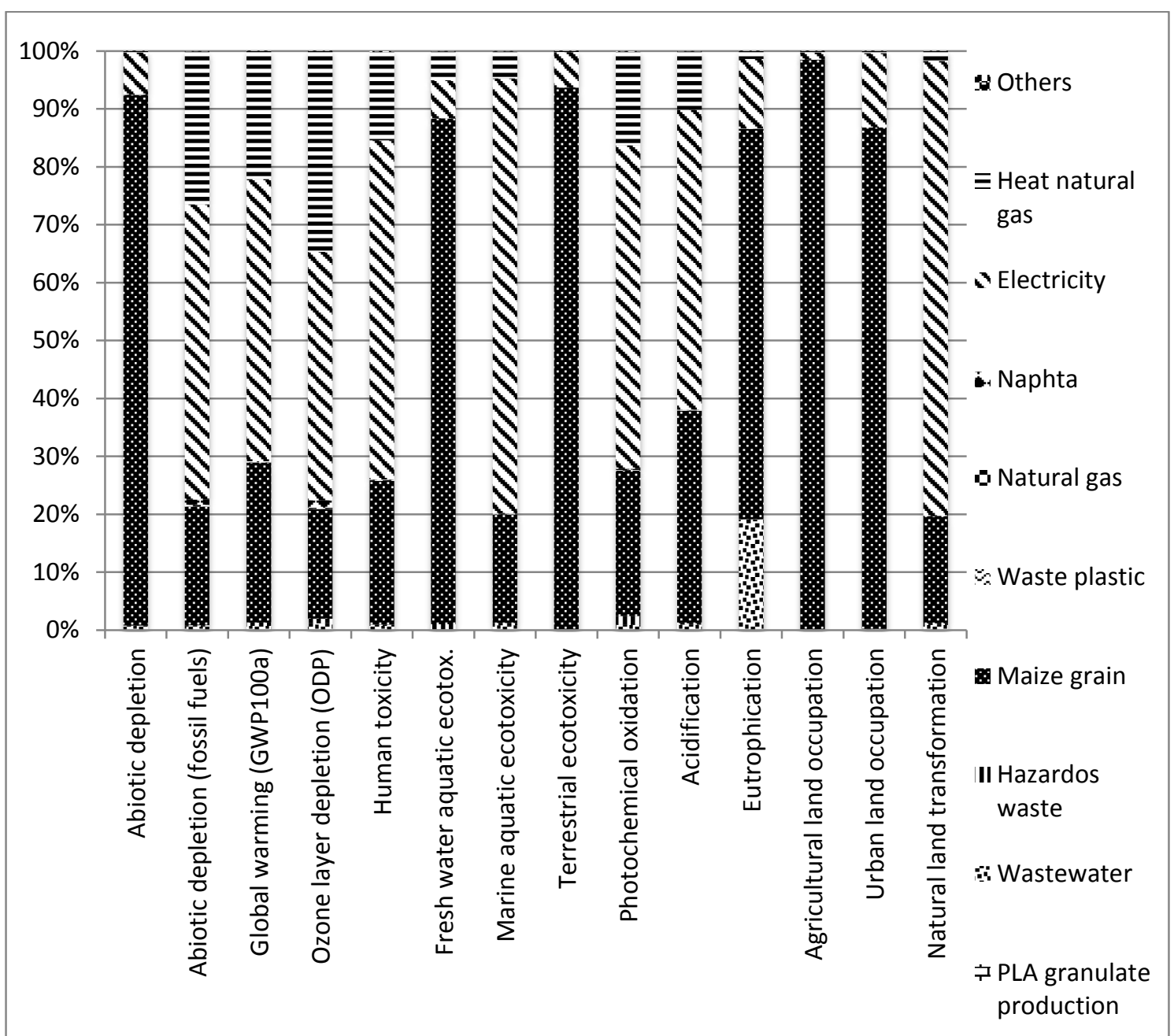

Figure 4: CML Characterization factors of PLA with CML-IA EU25 modified method and excluding infrastructure processes and long-term emissions. 
Table I: Stabilization and crushing processes inventory data.

\begin{tabular}{|c|c|c|c|c|c|}
\hline Step & Materials and energy & $\begin{array}{l}\text { Value } \\
\text { per } g \text { of } \\
\text { material } \\
\text { input of } \\
\text { the } \\
\text { process }\end{array}$ & Unit & $\begin{array}{l}\text { Value } \\
\text { per } g \text { of } \\
\text { SCCF }\end{array}$ & Unit \\
\hline \multicolumn{6}{|c|}{ Stabilization process Autoclave } \\
\hline Inputs & $\begin{array}{l}\text { Chicken feathers }(\mathrm{CF}) \\
(41 \% \text { of water content) }\end{array}$ & 1.0 & $\mathrm{~g}$ & 2.2 & $\begin{array}{l}\mathrm{g} / \mathrm{g} \\
\mathrm{SCCF}\end{array}$ \\
\hline The & Electricity & 1.1 & $\mathrm{~kJ} / \mathrm{gCF}$ & 2.4 & $\begin{array}{c}\mathrm{kJ} / \mathrm{g} \\
\mathrm{SCCF}\end{array}$ \\
\hline & Deionised water & 40.0 & $\mathrm{~g} / \mathrm{gCF}$ & 88.9 & $\begin{array}{c}\mathrm{g} / \mathrm{g} \\
\mathrm{SCCF}\end{array}$ \\
\hline Outputs Wastewater & COD & 12.9 & $\mathrm{mg} / \mathrm{gCF}$ & 28.7 & $\begin{array}{l}\mathrm{mg} / \mathrm{g} \\
\mathrm{SCCF}\end{array}$ \\
\hline & $\mathrm{BOD}_{5}$ & 0.7 & $\mathrm{mg} / \mathrm{gCF}$ & 1.6 & $\begin{array}{l}\mathrm{mg} / \mathrm{g} \\
\mathrm{SCCF}\end{array}$ \\
\hline & Suspended solids & 0.06 & $\mathrm{mg} / \mathrm{gCF}$ & 0.1 & $\begin{array}{l}\mathrm{mg} / \mathrm{g} \\
\mathrm{SCCF}\end{array}$ \\
\hline & Oils & 0.1 & $\mathrm{mg} / \mathrm{gCF}$ & 0.2 & $\begin{array}{l}\mathrm{mg} / \mathrm{g} \\
\mathrm{SCCF}\end{array}$ \\
\hline & Total nitrogen & 1.0 & $\mathrm{mg} / \mathrm{gCF}$ & 2.2 & $\begin{array}{l}\mathrm{mg} / \mathrm{g} \\
\mathrm{SCCF}\end{array}$ \\
\hline Intermediate product & Stabilized feathers (SCF) & 0.5 & $\mathrm{~g} / \mathrm{gCF}$ & 1.1 & $\begin{array}{c}\mathrm{g} / \mathrm{g} \\
\mathrm{SCCF}\end{array}$ \\
\hline \multicolumn{6}{|c|}{ Stabilization process Surfactant } \\
\hline Inputs & $\begin{array}{l}\text { Chicken feathers }(\mathrm{CF}) \\
(41 \% \text { of water content) }\end{array}$ & 1.0 & $\mathrm{~g}$ & 2.8 & $\begin{array}{c}\mathrm{g} / \mathrm{g} \\
\mathrm{SCCF}\end{array}$ \\
\hline & Electricity & 12.5 & $\mathrm{~kJ} / \mathrm{gCF}$ & 34.7 & $\begin{array}{c}\mathrm{kJ} / \mathrm{g} \\
\mathrm{SCCF}\end{array}$ \\
\hline & Deionised water & 240 & $\mathrm{~g} / \mathrm{gCF}$ & 667 & $\begin{array}{c}\mathrm{g} / \mathrm{g} \\
\mathrm{SCCF}\end{array}$ \\
\hline Surfactant & Dimethylamine & 0.15 & $\mathrm{~g} / \mathrm{gCF}$ & 0.4 & $\begin{array}{c}\mathrm{g} / \mathrm{g} \\
\mathrm{SCCF}\end{array}$ \\
\hline & Benzil chloride & 0.08 & $\mathrm{~g} / \mathrm{gCF}$ & 0.2 & $\begin{array}{c}\mathrm{g} / \mathrm{g} \\
\mathrm{SCCF}\end{array}$ \\
\hline & Sodium hydroxide $25 \%$ & 0.32 & $\mathrm{mg} / \mathrm{gCF}$ & 0.94 & $\begin{array}{l}\mathrm{mg} / \mathrm{g} \\
\mathrm{SCCF}\end{array}$ \\
\hline & Deinonized water & 0.04 & $\mathrm{~g} / \mathrm{gCF}$ & 0.1 & $\begin{array}{c}\mathrm{g} / \mathrm{g} \\
\mathrm{SCCF}\end{array}$ \\
\hline & Isopropanol & 0.01 & $\mathrm{~g} / \mathrm{gCF}$ & 0.03 & $\begin{array}{c}\mathrm{g} / \mathrm{g} \\
\mathrm{SCCF}\end{array}$ \\
\hline Outputs Wastewater & $\mathrm{COD}$ & 780.7 & $\mathrm{mg} / \mathrm{gCF}$ & 2169 & $\begin{array}{l}\mathrm{mg} / \mathrm{g} \\
\mathrm{SCCF}\end{array}$ \\
\hline & $\mathrm{BOD}_{5}$ & 50.2 & $\mathrm{mg} / \mathrm{gCF}$ & 139 & $\begin{array}{l}\mathrm{mg} / \mathrm{g} \\
\mathrm{SCCF}\end{array}$ \\
\hline & Suspended solids & 49.7 & $\mathrm{mg} / \mathrm{gCF}$ & 138 & $\begin{array}{l}\mathrm{mg} / \mathrm{g} \\
\mathrm{SCCF}\end{array}$ \\
\hline & Oils & 0.02 & $\mathrm{mg} / \mathrm{gCF}$ & 0.06 & $\begin{array}{l}\mathrm{mg} / \mathrm{g} \\
\mathrm{SCCF}\end{array}$ \\
\hline
\end{tabular}




\begin{tabular}{|c|r|r|r|r|c|}
\hline \multicolumn{2}{|c|}{ Total nitrogen } & 14.4 & $\mathrm{mg} / \mathrm{gCF}$ & 40.0 & $\begin{array}{c}\mathrm{mg} / \mathrm{g} \\
\mathrm{SCCF}\end{array}$ \\
\hline Intermediate product & Stabilized feathers (SCF) & 0.4 & $\mathrm{~g} / \mathrm{gCF}$ & 1.1 & $\begin{array}{c}\mathrm{g} / \mathrm{g} \\
\mathrm{SCCF}\end{array}$ \\
\hline Crushing process & \multicolumn{2}{|c|}{1.0} & $\mathrm{~g}$ & 1.1 & $\begin{array}{c}\mathrm{g} / \mathrm{g} \\
\mathrm{SCCF}\end{array}$ \\
\hline Intermediate product & Stabilized feathers (SCF) & 14.1 & $\mathrm{~kJ} / \mathrm{gSCF}$ & 15.7 & $\begin{array}{c}\mathrm{kJ} / \mathrm{g} \\
\mathrm{SCCF}\end{array}$ \\
\hline Inputs & Electricity & 0.9 & $\mathrm{~g} / \mathrm{gSCF}$ & 1.0 & $\begin{array}{c}\mathrm{g} / \mathrm{g} \\
\mathrm{SCCF}\end{array}$ \\
\hline Outputs & $\begin{array}{l}\text { Stabilized crushed feathers } \\
\text { (SCCF) }\end{array}$ &
\end{tabular}


Table II: Inventory data for the preparation of composite plates of $184 \times 184 \times 2.2 \mathrm{~mm}^{3}$ with different percentages of CFs as filler (FU represent the functional unit).

\begin{tabular}{|c|c|c|}
\hline Materials and energy & Value & Unit \\
\hline \multicolumn{3}{|l|}{ Plate manufacturing process } \\
\hline \multicolumn{3}{|l|}{ Composite $100 \%$ PLA } \\
\hline Stabilized crushed feathers (SCCF) & 0 & $\mathrm{~g} / \mathrm{FU}$ \\
\hline PLA & 102.4 & $\mathrm{~g} / \mathrm{FU}$ \\
\hline Electricity & 761.5 & $\mathrm{~kJ} / \mathrm{FU}$ \\
\hline Output Plate & 1 & unit \\
\hline \multicolumn{3}{|l|}{ Composite $90 \%$ PLA - 10\% CFs } \\
\hline Stabilized crushed feathers (SCCF) & 7.9 & $\mathrm{~g} / \mathrm{FU}$ \\
\hline PLA & 92.2 & $\mathrm{~g} / \mathrm{FU}$ \\
\hline Electricity & 759.9 & $\mathrm{~kJ} / \mathrm{FU}$ \\
\hline Output Plate & 1 & unit \\
\hline \multicolumn{3}{|l|}{ Composite $80 \%$ PLA - $20 \%$ CFs } \\
\hline Stabilized crushed feathers (SCCF) & 15.7 & $\mathrm{~g} / \mathrm{FU}$ \\
\hline PLA & 81.9 & $\mathrm{~g} / \mathrm{FU}$ \\
\hline Electricity & 758.2 & $\mathrm{~kJ} / \mathrm{FU}$ \\
\hline Output $\quad$ Plate & 1 & unit \\
\hline \multicolumn{3}{|l|}{ Composite $65 \%$ PLA - 35\% CFs } \\
\hline Stabilized crushed feathers (SCCF) & 27.5 & $\mathrm{~g} / \mathrm{FU}$ \\
\hline PLA & 66.6 & $\mathrm{~g} / \mathrm{FU}$ \\
\hline Electricity & 755.8 & $\mathrm{~kJ} / \mathrm{FU}$ \\
\hline Output Plate & 1 & unit \\
\hline
\end{tabular}


Table III: Characterization data of $1 \mathrm{~kg}$ of stabilized chicken feathers (SCF) with autoclave and surfactant using CML-IA EU25 modified method and excluding infrastructure processes and long term emissions.

\begin{tabular}{|l|l|l|l|}
\hline \multicolumn{1}{|c|}{ Impact category } & \multicolumn{1}{|c|}{ Unit } & \multicolumn{1}{|c|}{$\begin{array}{c}\text { Autoclave } \\
\text { stabilized } \\
\text { CFs }\end{array}$} & $\begin{array}{c}\text { Surfactant } \\
\text { stabilized } \\
\text { CFs }\end{array}$ \\
\hline Abiotic depletion & $\mathrm{kg} \mathrm{Sb} \mathrm{eq}$ & $3.57 \mathrm{E}-08$ & $9.65 \mathrm{E}-07$ \\
\hline Abiotic depletion (fossil fuels) & $\mathrm{MJ}$ & $0.60 \mathrm{E}+01$ & $1.03 \mathrm{E}+02$ \\
\hline Global warming (GWP100a) & $\mathrm{kg} \mathrm{CO}$ eq & $4.10 \mathrm{E}+01$ & $0.59 \mathrm{E}+01$ \\
\hline Ozone layer depletion (ODP) & $\mathrm{kg} \mathrm{CFC}-11$ eq & $6.41 \mathrm{E}-08$ & $8.06 \mathrm{E}-07$ \\
\hline Human toxicity & $\mathrm{kg} 1,4-\mathrm{DB}$ eq & $3.84 \mathrm{E}-02$ & $5.72 \mathrm{E}-01$ \\
\hline Fresh water aquatic ecotox. & $\mathrm{kg} 1,4-\mathrm{DB}$ eq & $4.94 \mathrm{E}-03$ & $1.07 \mathrm{E}-01$ \\
\hline Marine aquatic ecotoxicity & $\mathrm{kg} \mathrm{1,4-DB} \mathrm{eq}$ & $2.74 \mathrm{E}+02$ & $3.42 \mathrm{E}+03$ \\
\hline Terrestrial ecotoxicity & $\mathrm{kg} \mathrm{1,4-DB} \mathrm{eq}$ & $2.09 \mathrm{E}-04$ & $2.59 \mathrm{E}-03$ \\
\hline Photochemical oxidation & $\mathrm{kg} \mathrm{C} \mathrm{H}_{4}$ eq & $9.70 \mathrm{E}-05$ & $1.88 \mathrm{E}-03$ \\
\hline Acidification & $\mathrm{kg} \mathrm{SO}_{2}$ eq & $2.42 \mathrm{E}-03$ & $3.53 \mathrm{E}-02$ \\
\hline Eutrophication & $\mathrm{kg} \mathrm{PO}_{4}^{-3}$ eq & $7.58 \mathrm{E}-04$ & $4.59 \mathrm{E}-02$ \\
\hline Agricultural land occupation & $\mathrm{m}^{2}$ year & $5.26 \mathrm{E}-03$ & $6.21 \mathrm{E}-02$ \\
\hline Urban land occupation & $\mathrm{m}^{2}$ year & $1.47 \mathrm{E}-03$ & $1.75 \mathrm{E}-02$ \\
\hline Natural land transformation & $\mathrm{m}^{2}$ year & $9.29 \mathrm{E}-06$ & $1.10 \mathrm{E}-04$ \\
\hline & & & \\
\hline
\end{tabular}


Table IV: Characterization factors values of composite plate with $20 \%$ of CFs with CML-IA EU25 modified method and excluding infrastructure processes and long-term emissions.

\begin{tabular}{|c|c|c|c|c|c|c|c|c|}
\hline Impact category & Unit & Total & PLA production & $\begin{array}{c}\% \text { PLA } \\
\text { production }\end{array}$ & $\begin{array}{c}\text { CFs } \\
\text { production }\end{array}$ & $\begin{array}{c}\% \mathrm{CFs} \\
\text { production }\end{array}$ & $\begin{array}{l}\text { Composite } \\
\text { production }\end{array}$ & $\begin{array}{l}\text { \% Composite } \\
\text { production }\end{array}$ \\
\hline Abiotic depletion & $\mathrm{kg} \mathrm{Sb}$ eq & $5.72 \mathrm{E}-05$ & $5.70 \mathrm{E}-05$ & $99.98 \%$ & 4.80E-09 & $0.01 \%$ & $8.40 \mathrm{E}-09$ & $0.01 \%$ \\
\hline Abiotic depletion (fossil fuels) & MJ & $3.30 \mathrm{E}+03$ & $3.30 \mathrm{E}+03$ & $99.93 \%$ & 8.30E-01 & $0.03 \%$ & $1.40 \mathrm{E}+00$ & $0.04 \%$ \\
\hline Global warming (GWP100a) & $\mathrm{kg} \mathrm{CO}_{2} \mathrm{eq}$ & $2.46 \mathrm{E}+02$ & $2.50 \mathrm{E}+02$ & $99.94 \%$ & $5.60 \mathrm{E}-02$ & $0.02 \%$ & $9.80 \mathrm{E}-02$ & $0.04 \%$ \\
\hline Ozone layer depletion (ODP) & $\mathrm{kg}$ CFC-11 eq & $1.09 \mathrm{E}-05$ & $1.10 \mathrm{E}-05$ & $99.81 \%$ & 7.70E-09 & $0.07 \%$ & $1.30 \mathrm{E}-08$ & $0.12 \%$ \\
\hline Human toxicity & $\mathrm{kg} 1.4-\mathrm{DB}$ eq & $2.52 \mathrm{E}+01$ & $2.50 \mathrm{E}+01$ & $99.95 \%$ & $4.80 \mathrm{E}-03$ & $0.02 \%$ & 8.00E-03 & $0.03 \%$ \\
\hline Fresh water aquatic ecotox. & kg 1.4-DB eq & $2.00 \mathrm{E}+01$ & $2.00 \mathrm{E}+01$ & $99.99 \%$ & $6.90 \mathrm{E}-04$ & $0.00 \%$ & $1.20 \mathrm{E}-03$ & $0.01 \%$ \\
\hline Marine aquatic ecotoxicity & kg 1.4-DB eq & $1.19 \mathrm{E}+05$ & $1.20 \mathrm{E}+05$ & $99.92 \%$ & $3.70 \mathrm{E}+01$ & $0.03 \%$ & $6.30 \mathrm{E}+01$ & $0.05 \%$ \\
\hline Terrestrial ecotoxicity & kg 1.4-DB eq & 5.67E-01 & $5.70 \mathrm{E}-01$ & $99.98 \%$ & $3.10 \mathrm{E}-05$ & $0.01 \%$ & $5.60 \mathrm{E}-05$ & $0.01 \%$ \\
\hline Photochemical oxidation & $\mathrm{kg} \mathrm{C}_{2} \mathrm{H}_{4}$ eq & $5.78 \mathrm{E}-02$ & $5.80 \mathrm{E}-02$ & $99.94 \%$ & $1.30 \mathrm{E}-05$ & $0.02 \%$ & $2.20 \mathrm{E}-05$ & $0.04 \%$ \\
\hline Acidification & $\mathrm{kg} \mathrm{SO}_{2} \mathrm{eq}$ & $1.59 \mathrm{E}+00$ & $1.60 \mathrm{E}+00$ & $99.95 \%$ & $3.20 \mathrm{E}-04$ & $0.02 \%$ & $5.40 \mathrm{E}-04$ & $0.03 \%$ \\
\hline Eutrophication & $\mathrm{kg} \mathrm{PO}_{4}^{-3-}$ eq & $4.56 \mathrm{E}-01$ & $4.60 \mathrm{E}-01$ & $99.98 \%$ & 4.50E-05 & $0.01 \%$ & $3.80 \mathrm{E}-05$ & $0.01 \%$ \\
\hline Agricultural land occupation & $\mathrm{m}^{2}$ year & $8.54 \mathrm{E}+01$ & $8.50 \mathrm{E}+01$ & $100.00 \%$ & $5.70 \mathrm{E}-04$ & $0.00 \%$ & $8.90 \mathrm{E}-04$ & $0.00 \%$ \\
\hline Urban land occupation & $\mathrm{m}^{2}$ year & $4.66 \mathrm{E}+00$ & $4.70 \mathrm{E}+00$ & $99.99 \%$ & $1.80 \mathrm{E}-04$ & $0.00 \%$ & $3.00 \mathrm{E}-04$ & $0.01 \%$ \\
\hline Natural land transformation & $\mathrm{m}^{2}$ year & $4.78 \mathrm{E}-03$ & $4.80 \mathrm{E}-03$ & $99.94 \%$ & $1.20 \mathrm{E}-06$ & $0.02 \%$ & $1.90 \mathrm{E}-06$ & $0.04 \%$ \\
\hline
\end{tabular}


Table V: Characterization data of raising and slaughtering chicken feathers (CFs) needed to perform a $80 \%$ PLA-20\% CFs plate using CML-IA method. Calculated using data from references[34, 44].

\begin{tabular}{|l|c|c|c|c|c|c|}
\hline \multirow{2}{*}{$\begin{array}{c}\text { Impact for a 80\% PLA - } \\
20 \% \text { CFs plate }\end{array}$} & $\begin{array}{c}\text { Abiotic } \\
\text { depletion }\end{array}$ & $\begin{array}{c}\text { Acidification } \\
\text { potential }\end{array}$ & $\begin{array}{c}\text { Eutrophication } \\
\text { potential }\end{array}$ & $\begin{array}{c}\text { Global } \\
\text { Warming } \\
\text { potential }\end{array}$ & $\begin{array}{c}\text { Terrestrial } \\
\text { ecotoxicity }\end{array}$ & $\begin{array}{c}\text { Photochemical } \\
\text { oxidation } \\
\text { potential }\end{array}$ \\
\cline { 2 - 7 } & $\mathrm{kg} \mathrm{Sb} \mathrm{eq}$ & $\mathrm{kg} \mathrm{SO}_{2} \mathrm{eq}$ & $\mathrm{kg} \mathrm{PO}_{4}^{3-} \mathrm{eq}$ & $\mathrm{kg} \mathrm{CO}_{2} \mathrm{eq}$ & $\begin{array}{c}\mathrm{kg} \\
1,4-\mathrm{DCB} \text { eq }\end{array}$ & $\mathrm{kg} \mathrm{C}_{2} \mathrm{H}_{4} \mathrm{eq}$ \\
\hline $\begin{array}{l}\text { Portuguese broiler } \\
\text { chicken [34] }\end{array}$ & $3.82 \mathrm{E}-03$ & $1.99 \mathrm{E}-02$ & $9.21 \mathrm{E}-03$ & $1.09 \mathrm{E}+00$ & - & $1.54 \mathrm{E}-03$ \\
\hline $\begin{array}{l}\text { France broiler chicken } \\
\text { (standard system)[44] }\end{array}$ & - & $1.80 \mathrm{E}-02$ & $9.36 \mathrm{E}-03$ & - & $3.87 \mathrm{E}-03$ & - \\
\hline $\begin{array}{l}\text { France broiler chicken } \\
\text { ("Label Rouge")[44] }\end{array}$ & - & $2.96 \mathrm{E}-02$ & $1.28 \mathrm{E}-02$ & - & $6.07 \mathrm{E}-03$ & - \\
\hline $\begin{array}{l}\text { Brazil broiler chicken } \\
\text { (large-scale system)[44] }\end{array}$ & - & $1.99 \mathrm{E}-02$ & $9.45 \mathrm{E}-03$ & - & $4.35 \mathrm{E}-03$ & - \\
\hline $\begin{array}{l}\text { Brazil broiler chicken } \\
\text { (small-scale system)[44] }\end{array}$ & - & $2.18 \mathrm{E}-02$ & $9.74 \mathrm{E}-03$ & - & $4.46 \mathrm{E}-03$ & - \\
\hline Average of scenarios & $3.82 \mathrm{E}-03$ & $2.18 \mathrm{E}-02$ & $1.01 \mathrm{E}-02$ & $1.09 \mathrm{E}+00$ & $4.69 \mathrm{E}-03$ & $1.54 \mathrm{E}-03$ \\
\hline $\begin{array}{l}\text { Composite production } \\
\text { impact }\end{array}$ & $5.72 \mathrm{E}-05$ & $1.59 \mathrm{E}+00$ & $4.56 \mathrm{E}-01$ & $2.46 \mathrm{E}+02$ & $5.67 \mathrm{E}-01$ & $5.78 \mathrm{E}-02$ \\
\hline Total impact & $3.88 \mathrm{E}-03$ & $1.61 \mathrm{E}+00$ & $4.66 \mathrm{E}-01$ & $2.47 \mathrm{E}+02$ & $5.72 \mathrm{E}-01$ & $5.93 \mathrm{E}-02$ \\
\hline $\begin{array}{l}\text { \% of raising and } \\
\text { slaughtering CFs over the } \\
\text { total plate EIs }\end{array}$ & $9.80 \mathrm{E}-01$ & $1.35 \mathrm{E}-02$ & $2.17 \mathrm{E}-02$ & $4.40 \mathrm{E}-03$ & $8.20 \mathrm{E}-03$ & $2.59 \mathrm{E}-02$ \\
\hline
\end{tabular}

